\title{
The Use of Deixis in the Students' Writing Narrative Texts
}

\author{
Isma Hidayati ${ }^{1}$, Sulisyaningsih ${ }^{2}$, Abd. Syakur ${ }^{3}$ \\ ${ }^{1,2,3}$ STKIP PGRI Sidoarjo, Indonesia \\ ismahidayati27@gmail.com, sulistyaningsih3112@gmail.com,syakurabdmpd@gmail.com
}

\begin{abstract}
The study's goal was to identify different types of deixis and types of errors found in students' narrative text writing. There is person deixis, which is the name of the person in the story, spatial deixis, which is the location of the story, temporal deixis, which is the time when the story events, social deixis, which is the social in the surrounding environment, and discourse deixis, which is the part or the next chapter of the story (Levinson, 1983). The descriptive qualitative method was used in this study. The subjects were eight 10th grade students from SMK IKIP Gedangan in Sidoarjo. The instrument in this study was the students' work who took the remedial because their score was less than 70 . Students were assigned to write Narrative texts by the teacher. The data was analyzed, examined, and a conclusion was reached based on the deixis. The researchers discovered deixis and error analysis in student writing. There are kind deixis of stories in narrative text that students written like temporal deixis, person deixis, spatial deixis, social deixis, and deixis discourse. For the error analysis there are ommission, addition, misinformation and misordering.
\end{abstract}

Keywords

Deixis; writing; error analysis

\section{Introduction}

Language is the primary tool used in communication. Sometimes the goal of communication is not met satisfactorily. As a result, people must learn about language in order to avoid misunderstandings and misinterpretations between the speaker and the hearer (Slamet \& Sulistyaningsih, 2019). Pragmatics is one of the fields of study in language learning. Pragmatics is a field of study that examines the meaning of language in its context. According to Levinson (1983, p. 9), pragmatics is the study of the relationships between language and context that are encoded in language structure which found in pragmatics context. Pragmatics is the relationship between language and context which connecting writing of grammar by (Levinson, 1983). Deixis is form that include in pragmatics that have two parts of written and spoken with found the meaning of people said to the deictic words by (Kusumaningrum, 2016) in writing actually can classify when we analyze the deixis with narrative text students' writing. The researchers looked around the environment that she does teaching in her school, the students like to speak and tell story with their friends or they advance it to explore their knowledge to be the writing in narrative text.

Language is one of the most important things in the life of every human being. Each of them is of course inseparable from language, the first time a child gets a language that is heard directly from the father or mother when the child is born into this world. Then as time goes by and as the child grows, they will acquire a language other than the language taught by the mother and father, either in the form of a second, third, foreign language or so on which is called language acquisition where it depends on the social environment and cognitive level possessed by these children through the learning process in their environment (Purba, N. et al. (2020). 
Narrative text is one of the parts of literary work of spoken or written by the story's events. According to (Maulana, 2016) Narrative text is the story that contains the texts as follows from orientation, complication and resolution. The narrative text is important because it can telling the story how is the events and what is the solution to finish story's problem. The purpose of the study is to know how many deixis and error analysis that finds in students' writing narrative text. When the researcher gets the observation in the classroom many students is very unconfident to write their writing and usually students still confuse about what they want to write, when the students have the assignments from the teacher, they are still thinking about what will their write. The researcher as their teacher looked students every day that the students always telling their story from their life so, the researcher take the material of narrative text.

According to (Purba, 2018) Narrative Text is one of the techniques to improve students writing with reading the story and write the story even the application by the discussion and from students' diary notes that they told their story by themselves this is can improvement the technique of story starter in writing, this is like write story on the paper and apply by telling story with their friends.

Based on (Silalahi, 2016) she states that pragmatics is relatively late entrants into linguistics in the late 1970. However, many people said this is a rather new area. The structures of linguistics consist of parts language analyzes. Pragmatics can be use how to utterance the meaning and the relation of the speaker's language. Semantics is the study about express meaning, how language organizes and study of meaning by (Kreidler, 1997). The reason of the researcher chooses to analyze deixis in students' writing because writing is one of the important skills that include from listening, reading and speaking. Especially writing based on (Karolina, 2006) states writing is the one of difficult subject for students in their school so, teacher must teach it to be easy lesson and teacher can find out the really good text for teaching writing. By the statement above, the researcher thought that writing is the one part from 4 skills and it is easy when we want to prepare study about the all skills and it can be analyzed deixis classification.

According to (Kapur, 2018) the significance of the study in research is focused on solution and understands the purpose of research. From explanation above the researcher give significance of the study for reader, education and the other researcher, follows: for reader hope can get the information of deixis about types deixis and error deixis, for education wishes the teacher in the classroom understand that the deixis can analysis by the classification and for the other researcher can give knowledge to the further research for more deeper research about deixis like kinds and other types of deixis.

The deixis also called deictic. According to (Gafiyatova, Korovina, Solnyshkina, \& Yarmakeev, 2017) Deictic is the important elements that considered in develop the text with the expression meaning. The word of deixis is including in the deictic expression. The explanation from (Hutauruk, 2018) Deictic expression is the gesture and technique to interaction with utterance. According to (Wibowo, 2013) writing is the communication like writing short message. In the other hand, one of the study include in four skills in one part that the researcher take in this research. Writing is very important skills that people want to do notes. Beside to (Defazio, Jones, Tennant, \& Hook, 2010) writing is the exercise of application in learning to get the experiences. Writing is the easy subject in creativity because writing has the types. Actually, many type of writing. This is supported by (Avagyan, 2019) like writing narrative text that written by person of the story telling, descriptive text is the describe character, place and the situation; expository is the writing that explain about the topic and the facts that include in deixis. 
Deixis is including in pragmatics. According to (Sari, 2015) deixis is the meaning of words to understand the information. Deixis there is in the pragmatics. Based on (Hasanah, 2016) Pragmatics is the meaning of language that communicates by the utterances. The deixis is one of parts semantics. The meaning of semantics by (Novianty, Saleh, \& Sukmawaty, 2018) is the process deictic expression with reference of meaning solution. Deixis consist of some parts to analyze in writing and have function to know the meaning this is supported by (Nurhikmah, 2017) that deixis have function to know the meaning transmitted when the deixis is find by the classification. The researcher tells deixis can be analysis during the story events.

Referring to the deictic words that are used to represent the various types of deixis references. According to Levinson (1983), there are five kinds of deixis: (1) Person deixis refers to the grammatical categories of person, and it includes pronouns that refer to the speaker, hearer, and other entities relevant to the discourse. It is divided into three sections: first person (I, me, etc.), second person (you, your, yours), and third person (you, your, yours) (she, they, etc). (2) Time deixis refers to the categories of time at which the speaker is producing the utterance and can also refer to a specific moment. For example, now, yesterday, and so on. (3) Place deixis refers to the assignment of locations to points in a speech event. For example, here, at school, and so on. (4) Social deixis refers to the aspects of speech events that are influenced by certain realities of social status. For example, Prof, Sir, and so on. (5) Discourse deixis refers to the use of expressions within an utterance to refer to a specific portion of the discourse and it contains. For example: that, this, and so on.

The previous study from (Patmo, 2017) the title of An Analysis of Deixis and Speech Act Used in English Teaching and Learning Process. He stated that deixis is a part of pragmatics related with sentence because the context can be changed. The sentences change of situation such as personal, time and place. This is used quantative research in eleventh grade students of language in EFL classroom. The researcher used descriptive qualitative analysis by the theory from (Levinson, 1983) The differences are the researcher take deixis on deixis students' narrative text in the classroom with the students' story or from English module. Second of previous study from Gadis Supandini (2016) The Study of Deixis Used in Shierly Jackson's Short Story "The Lottery" stated that in the sentence or utterance usually find about three kinds of deixis like person, spatial is place and temporal is time, this is use qualitative some with this research but the researchers used writing narrative text and another researcher use the short story. This research is important to conduct because in writing students' only written without, they categorized the deixis classification. The different is the researcher research the type of deixis and error deixis in the students' writing.

From the statements above the researcher get the statement of the problems that will analyze by two question first is what types of deixis are used by the students in narrative texts and second is what types of error done by the students in narrative texts. The objectives of the study are to know types of deixis are used by the students in narrative texts and to describe types of error done by the students in narrative texts.

\section{Research Method}

This researchs used qualitative analysis so, the main instrument was the researcher theirselves. The data technique was analyzed using Levinson's deixis category and the triangulator will be someone who knows well about the English deixis. The first theory from (Levinson, 1983) that deixis has five forms among others. There is person deixis is 
the name of the person in the story, spatial deixis is the place of the story, temporal deixis is the time when the story events, social deixis is the social in the around environment and the deixis of discourse is the part or the next chapter of the story. The second theory from (Dulay, Burt, \& Krashen, 1982) describes the errors deixis use in narrative texts analysis as follows: omission the meaning is negative false, addition is taking two or more number and adding them together, misformation is the characterized by use the wrong form of the morpheme and misordering the error of putting words in the utterance in the wrong order.

The data take from SMK IKIP PGRI, Sidoarjo in the students' semester one in the English Foreign Language classroom. The subject is the students of 10th grade in vocational high school there are eighteen students in one class but, the researcher chose eight students who the researcher took the data because it had time to repair their value in English lesson and the researcher asked them to write narrative text after their mid term test.

Meanwhile, the researcher used pragmatics field rules as the approach in analyzing the discourse when analyzing the data. That is the deixis theory proposed by Stephen C Levinson (1983). It can be seen in the emergence of some deictic words. The researcher took several steps while analyzing the data. First, the researchers carefully examine each text in accordance with the deixis rules. Then look for some questions like classification types of deixis that appeared, which one was dominant, and why it was dominant. Finally, the researcher describes the findings by explaining them in the following discussion and findings section. The entire set of data is explained and described in narrative form.

\section{Result and Discussion}

This section discusses the findings of the research. The researcher discovered some deictic words used in narrative texts after analyzing the data. The outcome was discovered by employing Stephen C Levinson's (1983) theory, which stated that there are five types of deixis. Almost every type of deixis was found in the texts. This paper also includes some representation from each text to demonstrate some of them. The researcher analyzes the data to get the result, the researchers used the table classification below:

Table 1. Classification of Deixis

\begin{tabular}{|c|c|c|c|c|}
\hline No & Name & Narrative Text & Categories of Deixis & Explanation \\
\hline 1. & Imelda & $\begin{array}{l}\text { (1) Once upon a } \\
\text { time, (2) Dayang } \\
\text { Sumbi } \\
\text { Sangkuriang, and } \\
\text { forest, (4) People } \\
\text { didn't } \quad \text { know } \\
\text { anything about } \\
\text { Dayang Sumbi, (5) } \\
\text { Several years later } \\
\text { Error Analysis: (1) } \\
\text { Saveral, (2) Verry, } \\
\text { (3) tough condifions, } \\
\text { (4) of take house } \\
\text { bring his heart }\end{array}$ & $\begin{array}{l}\text { Deixis: First is temporal } \\
\text { deixis, because showed } \\
\text { about time. Second is } \\
\text { Person Deixis because there } \\
\text { is name of the person. } \\
\text { Third is spatial deixis } \\
\text { because there is a place. } \\
\text { Fourth is social. Fifth is } \\
\text { discourse } \\
\text { Error Analysis: First is } \\
\text { Ommission, Second is } \\
\text { Addition, Third is } \\
\text { Misinformation, Fourth is } \\
\text { Misordering }\end{array}$ & $\begin{array}{l}\text { The kind of Deixis first is once upon } \\
\text { a time because showed about time, } \\
\text { second is Dayang Sumbi and } \\
\text { Sangkuriang because it is the name } \\
\text { of women. Third forest because the } \\
\text { place. Fourth is in the sociality } \\
\text { Dayang Sumbi is not social human } \\
\text { showed social deixis Fifth is Several } \\
\text { years later that showed about the } \\
\text { next of the part in the story. } \\
\text { Error Analysis: omission the } \\
\text { meaning is negative false because } \\
\text { the right answer is "Several". Second } \\
\text { is addition that taking two or more } \\
\text { number and adding them together the } \\
\text { right answer is "Very", misformation }\end{array}$ \\
\hline
\end{tabular}




\begin{tabular}{|c|c|c|c|c|}
\hline & & & & $\begin{array}{l}\text { is the characterized by use the wrong } \\
\text { form of the morpheme because the } \\
\text { right answer is "Through Condition" } \\
\text { and forth is misordering the error of } \\
\text { putting words in the utterance in the } \\
\text { wrong order because the right } \\
\text { answer is "Of Bring His Heart" }\end{array}$ \\
\hline 2. & Novia & $\begin{array}{l}\text { (1) One day, } \\
\text { (2) An Old man, } \\
\text { (3) Village, (4) } \\
\text { people avoid him } \\
\text { because he is mis- } \\
\text { fortune, (5) He } \\
\text { turned eighty years } \\
\text { old } \\
\text { Error Analysis: (1) } \\
\text { He was one of } \\
\text { unfortunate people } \\
\text { in the world, (2) } \\
\text { the old man about } \\
\text { whit happened, (3) } \\
\text { I've been chasiny } \\
\text { hapaness, (4) He } \\
\text { answeis }\end{array}$ & $\begin{array}{l}\text { Deixis: First is temporal } \\
\text { deixis, because showed } \\
\text { about time. Second is } \\
\text { Person Deixis because there } \\
\text { is name of the person. } \\
\text { Third is spatial deixis } \\
\text { because there is a place. } \\
\text { Fourth is social. Fifth is } \\
\text { discourse } \\
\text { Error Analysis: First is } \\
\text { Ommission, Second is } \\
\text { Addition, Third is } \\
\text { Misinformation, Fourth is } \\
\text { Misordering }\end{array}$ & $\begin{array}{l}\text { The kind of Deixis first is one day } \\
\text { because showed about time, second is } \\
\text { an old man because it is the person } \\
\text { Third village because the place. Fourth } \\
\text { is people avoid him that showed social } \\
\text { deixis, Fifth is eighty years old that } \\
\text { showed about the next of the part in the } \\
\text { story. } \\
\text { Error Analysis: omission because the } \\
\text { words "unfortunate" showed the } \\
\text { meaning of negative. Second is } \\
\text { addition that taking two or more } \\
\text { number and adding them together the } \\
\text { right answer is "What", misformation is } \\
\text { the characterized by use the wrong } \\
\text { form of the morpheme because the } \\
\text { right answer is "Chasinly Happiness" } \\
\text { and forth is misordering the error of } \\
\text { putting words in the utterance in the } \\
\text { wrong order because the right answer is } \\
\text { "He answer" }\end{array}$ \\
\hline 3. & Dewi & 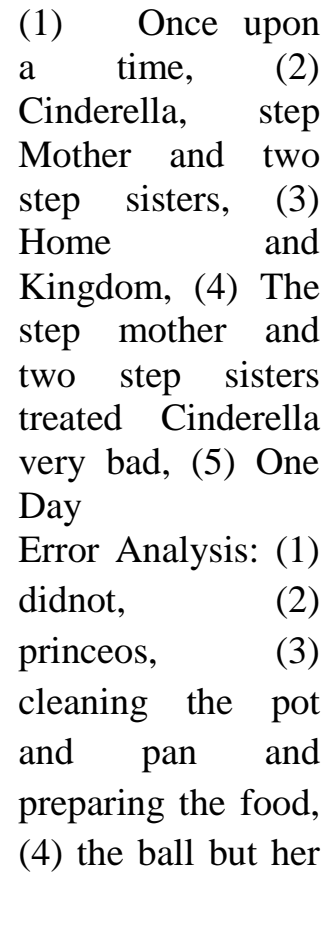 & $\begin{array}{l}\text { Deixis: First is temporal } \\
\text { deixis, because showed } \\
\text { about time. Second is } \\
\text { Person Deixis because there } \\
\text { is name of the person. } \\
\text { Third is spatial deixis } \\
\text { because there is a place. } \\
\text { Fourth is social. Fifth is } \\
\text { discourse } \\
\text { Error Analysis: First is } \\
\text { Ommission, Second is } \\
\text { Addition, Third is } \\
\text { Misinformation, Fourth is } \\
\text { Misordering }\end{array}$ & $\begin{array}{l}\text { The kind of Deixis first is once upon } \\
\text { a time because showed about time, } \\
\text { second is Cinderella, step Mother } \\
\text { and two step sisters because it is the } \\
\text { name of women. Third Home and } \\
\text { Kingdom because the place. Fourth } \\
\text { is treated Cinderella very bad } \\
\text { showed social deixis Fifth is One } \\
\text { Day that showed about the next of } \\
\text { the part in the story. } \\
\text { Error Analysis: omission showed in } \\
\text { "did not" the meaning is negative } \\
\text { false. Second is addition that taking } \\
\text { two or more number and adding them } \\
\text { together the right answer is "Prince", } \\
\text { misformation is the characterized by } \\
\text { use the wrong form of the morpheme } \\
\text { because the right answer is "cleaning } \\
\text { the pot, pan and preparing the food" }\end{array}$ \\
\hline
\end{tabular}




\begin{tabular}{|c|c|c|c|c|}
\hline & & step mother. & & $\begin{array}{l}\text { and forth is misordering the error of } \\
\text { putting words in the utterance in the } \\
\text { wrong order because the right answer } \\
\text { is "The ball but, her step mother" }\end{array}$ \\
\hline 4. & Lia & $\begin{array}{l}\text { (1) Since } 9^{\text {th }} \\
\text { June until } 1^{\text {st }} \text { July, } \\
\text { around } 10 \mathrm{pm}, 7 \\
\text { o'clock in the } \\
\text { morning, we } \\
\text { reached there } \\
\text { within } 25 \text { minutes } \\
(2) \text { I and my } \\
\text { cousin, (3) Pasar } \\
\text { Turi station, } \\
\text { Hero's museum } \\
\text { (4) awesome } \\
\text { vocation, (5) After } \\
\text { breakfast } \\
\text { Error Analysis: (1) } \\
\text { spent many daus, } \\
\text { (2) I caunght a } \\
\text { train, (3) relak, } \\
\text { clased, (4) I and } \\
\text { my cousin. }\end{array}$ & $\begin{array}{l}\text { Deixis: First is temporal } \\
\text { deixis, because showed } \\
\text { about time. Second is } \\
\text { Person Deixis because there } \\
\text { is name of the person. } \\
\text { Third is spatial deixis } \\
\text { because there is a place. } \\
\text { Fourth is social. Fifth is } \\
\text { discourse } \\
\text { Error Analysis: First is } \\
\text { Ommission, Second is } \\
\text { Addition, Third is } \\
\text { Misinformation, Fourth is } \\
\text { Misordering }\end{array}$ & $\begin{array}{l}\text { The kind of Deixis first is 9th June } \\
\text { until } 1 \text { st July, } 7 \text { o'clock, } 25 \text { minutes } \\
\text { because showed about time, second is } \\
\text { I and My cousin because it is the } \\
\text { person. Third Pasar Turi station, } \\
\text { hero's museum because the place. } \\
\text { Fourth is in the sociality this vocation } \\
\text { is awesome showed social deixis Fifth } \\
\text { is After breakfast showed about the } \\
\text { next of the part in the story. } \\
\text { Error Analysis: omission the meaning } \\
\text { is negative false because the right } \\
\text { answer is "spend many days". Second } \\
\text { is addition that taking two or more } \\
\text { number and adding them together the } \\
\text { right answer is "caught", } \\
\text { misformation is the characterized by } \\
\text { use the wrong form of the morpheme } \\
\text { because the right answer is "Relax, } \\
\text { closed" and forth is misordering the } \\
\text { error put words the utterance in the } \\
\text { wrong order because the right answer } \\
\text { is "My cousin and I. }\end{array}$ \\
\hline 5. & Ainul & $\begin{array}{l}\text { (1) snow, (2) } \\
\text { hunters and } \\
\text { longers, (3) in the } \\
\text { woods, (4) just } \\
\text { looking a trace, (5) } \\
\text { where the lion are } \\
\text { nested } \\
\text { Error Analysis: (1) I } \\
\text { didn't ask, (2) } \\
\text { Singan, gemetaran } \\
\text { (3) loggecs, (4) } \\
\text { Hunters and longers } \\
\text { kayu seorang hunter. }\end{array}$ & $\begin{array}{l}\text { Deixis: First is temporal } \\
\text { deixis, because showed } \\
\text { about time. Second is } \\
\text { Person Deixis because there } \\
\text { is name of the person. } \\
\text { Third is spatial deixis } \\
\text { because there is a place. } \\
\text { Fourth is social. Fifth is } \\
\text { discourse } \\
\text { Error Analysis: First is } \\
\text { Ommission, Second is } \\
\text { Addition, Third is } \\
\text { Misinformation, Fourth is } \\
\text { Misordering }\end{array}$ & $\begin{array}{l}\text { The kind of Deixis first is snow } \\
\text { because showed about time when } \\
\text { snowing, second is hunters and } \\
\text { longers because it is the name. Third } \\
\text { woods because the place. Fourth is } \\
\text { looking a trace showed social deixis } \\
\text { Fifth is where the lion are nested } \\
\text { showed about the next of the part in } \\
\text { the story. } \\
\text { Error Analysis: omission showed in " } \\
\text { I did not ask" the meaning is negative } \\
\text { false. Second is addition that taking } \\
\text { more number and adding them } \\
\text { together the right answer is "The lion, } \\
\text { trembling", third misformation is the } \\
\text { characterized by use the wrong form } \\
\text { of the morpheme, the right answer is } \\
\text { "longers". fourth is misordering the } \\
\text { error of putting words in the utterance } \\
\text { in the wrong order, the right answer is }\end{array}$ \\
\hline
\end{tabular}




\begin{tabular}{|c|c|c|c|c|}
\hline & & & & $\begin{array}{l}\text { "Hunters and longers is carpenter } \\
\text { hunter" }\end{array}$ \\
\hline 6. & Fitri & $\begin{array}{l}\text { (1) One day, } \\
\text { Winter (2) A litle } \\
\text { duckling, Swan, an } \\
\text { old lady (3) home, } \\
\text { woods, lake, water, } \\
\text { (4) Nobody like } \\
\text { me, (5) Spring } \\
\text { arrived } \\
\text { Error Analysis: (1) } \\
\text { They'd not play with } \\
\text { him And titillated } \\
\text { the poor ugly } \\
\text { duckling, (2) her } \\
\text { cah, (3) Then again, } \\
\text { (4) thy were } \\
\text { duckling but I used } \\
\text { to be a baby swan. }\end{array}$ & $\begin{array}{l}\text { Deixis: First is temporal } \\
\text { deixis, because showed } \\
\text { about time. Second is } \\
\text { Person Deixis because there } \\
\text { is name of the person. } \\
\text { Third is spatial deixis } \\
\text { because there is a place. } \\
\text { Fourth is social. Fifth is } \\
\text { discourse } \\
\text { Error Analysis: First is } \\
\text { Ommission, Second is } \\
\text { Addition, Third is } \\
\text { Misinformation, Fourth is } \\
\text { Misordering. }\end{array}$ & $\begin{array}{l}\text { The kind of Deixis first is one day and } \\
\text { winter showed about time, second is } \\
\text { duckling, swan and an old lady } \\
\text { because it is the name. Third home, } \\
\text { woods, lake, water because the place. } \\
\text { Fourth is in the sociality nobody like } \\
\text { me showed social deixis Fifth is when } \\
\text { spring arrived showed about the next } \\
\text { of the part in the story. } \\
\text { Error Analysis: omission the meaning } \\
\text { is negative false because the right } \\
\text { answer is "they didn't play and } \\
\text { titillated the ugly duckling". Second is } \\
\text { addition that taking two or more } \\
\text { number and adding them together the } \\
\text { right answer is "her face", } \\
\text { misformation is the characterized by } \\
\text { use the wrong form of the morpheme } \\
\text { because the right answer is "Then" } \\
\text { and forth is misordering the error of } \\
\text { putting words in the utterance in the } \\
\text { wrong order because the right answer } \\
\text { is "but, I used to be baby swan" }\end{array}$ \\
\hline 7. & Angel & $\begin{array}{l}\text { (1) Once upon } \\
\text { a time, one day (2) } \\
\text { mother, people, } \\
\text { children, (3) Forest, } \\
\text { (4) take care, } \\
\text { treated carefully, } \\
\text { (5) After that, after } \\
\text { several days, till the } \\
\text { end } \\
\text { Error Analysis: (1) } \\
\text { an ugly cottage and } \\
\text { wore worn-out } \\
\text { dresses, (2) They } \\
\text { were so poor, for } \\
\text { some herbal (3) the } \\
\text { mother was getting } \\
\text { infected.And, since } \\
\text { her body was so } \\
\text { weak, (4) she passed } \\
\text { away after several } \\
\text { days. }\end{array}$ & $\begin{array}{l}\text { Deixis: First is temporal } \\
\text { deixis, because showed } \\
\text { about time. Second is } \\
\text { Person Deixis because there } \\
\text { is name of the person. } \\
\text { Third is spatial deixis } \\
\text { because there is a place. } \\
\text { Fourth is social. Fifth is } \\
\text { discourse } \\
\text { Error Analysis: First is } \\
\text { Ommission, Second is } \\
\text { Addition, Third is } \\
\text { Misinformation, Fourth is } \\
\text { Misordering }\end{array}$ & $\begin{array}{l}\text { The kind of Deixis first is once upon a } \\
\text { ime, one day showed about time, } \\
\text { second is mother, people, children it is } \\
\text { the person. Third forest because the } \\
\text { place. Fourth is in the take care and } \\
\text { treated carefully showed social deixis } \\
\text { Fifth is After that, after several days, } \\
\text { till the end showed about the next of } \\
\text { the part in the story. } \\
\text { Error Analysis: omission the meaning } \\
\text { is negative false because the right } \\
\text { answer is "an ugly cottage and wore } \\
\text { out dress". Second is addition that } \\
\text { taking two or more number and } \\
\text { adding them together the right answer } \\
\text { is "they were poor, for some herbals", } \\
\text { misforma- tion is the characterized by } \\
\text { use the wrong form of the morpheme } \\
\text { because the right answer is "the } \\
\text { mother was getting infected since her } \\
\text { body was weak," and forth is } \\
\text { misordering the error of putting words }\end{array}$ \\
\hline
\end{tabular}




\begin{tabular}{|c|c|c|c|c|}
\hline & & & & $\begin{array}{l}\text { in the utterance in the wrong order } \\
\text { because the right answer is "after } \\
\text { several days she passed away" }\end{array}$ \\
\hline 8. & Rani & $\begin{array}{l}\text { (1) Once upon a } \\
\text { time, (2) Cinderella, } \\
\text { step Mother and two } \\
\text { step sisters, (3) } \\
\text { Home and Kingdom, } \\
\text { (4) The step mother } \\
\text { and two step sisters } \\
\text { treated Cinderella } \\
\text { very bad, (5) One } \\
\text { Day } \\
\text { Error Analysis: (1) } \\
\text { didnot, (2) princeos } \\
\text { (3) cleaning the po } \\
\text { and pan and preparing } \\
\text { the food, (4) hes } \\
\text { mother-step. }\end{array}$ & $\begin{array}{l}\text { Deixis: First is temporal } \\
\text { deixis, because showed } \\
\text { about time. Second is } \\
\text { Person Deixis because } \\
\text { there is name of the person. } \\
\text { Third is spatial deixis } \\
\text { because there is a place. } \\
\text { Fourth is social. Fifth is } \\
\text { discourse } \\
\text { Error Analysis: First is } \\
\text { Ommission, Second is } \\
\text { Addition, Third is } \\
\text { Misinformation, Fourth is } \\
\text { Misordering }\end{array}$ & $\begin{array}{l}\text { The kind of Deixis first is once upon a } \\
\text { time because showed about time, } \\
\text { second is Cinderella, step Mother and } \\
\text { two step sisters because it is the name } \\
\text { of women. Third Home and Kingdom } \\
\text { because the place. Fourth is treated } \\
\text { Cinderella very bad showed social } \\
\text { deixis Fifth is One Day that showed } \\
\text { about the next of the part in the story. } \\
\text { Error Analysis: omission showed in } \\
\text { "did not" the meaning is negative } \\
\text { false. Second is addition that taking } \\
\text { two or more number and adding them } \\
\text { together the right answer is "Prince", } \\
\text { misformation is the characterized by } \\
\text { use the wrong form of the morpheme } \\
\text { because the right answer is "cleaning } \\
\text { the pot, pan and preparing the food" } \\
\text { and forth is misordering the error of } \\
\text { putting words in the utterance in the } \\
\text { wrong order because the right answer } \\
\text { is "her step mother" }\end{array}$ \\
\hline
\end{tabular}

Finally, it can be concluded from the table above that "person deixis" was found the most frequently, and this result is also related to the relevant research conducted by Anggara (2016). In their studies, they looked into both the person deixis and the phenomenon of deixis. Meanwhile, the dominant deictic word discovered by this research is the same as the result of Pratiwi's research (2018). She discovered the word 'he,' which referred to Prophet Muhammad SAW. Then, Abdulameer (2019) discovered that 'he' was the most commonly used deictic word. 'He' refers to God, which affects the listener. Meanwhile, in this study, the deictic word 'he' was used because the text's story was about retelling someone else's story. The stories were not sourced by the text's author. As a result, the subject or addressee was written in the third person. As a result, this study discovered the use of 'he' in the other interpretations.

As a result, the use of those them is determined by the type of written or spoken text itself. Not all of the deixis types are used or applied in those texts all of the time. In fact, the social deixis is absent from the text. It is because the text's genre is narrative, particularly fairy tale, and it is uncommon to use social deixis. Deictic words of each type, on the other hand, can be expressed in a variety of ways. As a result, it can have an impact in the calculation of frequently used terms. The researcher took theory from first researcher that research about the writing that the writing is the skills of one part the important skills that include in deixis. Deixis also supported by the second and third theory that explain about types of deixis and error deixis. The first is from (Defazio, Jones, Tennant, \& Hook, 2010) said that writing is the academic literacy that can develop students' writing skill in 
pedagogical by discussion about the assignment like deixis to know the objective and suggestion when assessment. The second is from (Levinson, 1983) he stated that pragmatics is the language aspect naturally by the reference with understanding the meaning of language in deixis. Third is from (Dulay, Burt, \& Krashen, 1982) they stated that the phrase and meaning understanding by the language in deixis is include in pragmatics that have data card to analyzed the error deixis. From the explanation above, the researchers took the research about kind of deixis and analyze error deixis in students' writing narrative texts.

The researchers described that deixis have first is temporal deixis, because showed about time. Second is Person Deixis because there is name of the person. Third is spatial deixis because there is a place. Fourth is social. Fifth is discourse and for the error analysis first is ommission, second is addition, third is misinformation, fourth is misordering this is supported by (Dulay, Burt, \& Krashen, 1982) and (Levinson, 1983) the theories are supported to know the types of deixis and types error deixis in students' writing Narrative text.

For the first, the student writes about "Sangkuriang" the story of Sangkuriang have some kinds of deixis like temporal deixis, person deixis, spatial deixis, social deixis and discourse when students' writing there are error analysis like ommission, addition, misinformation and misordering. Second, the student writes story about "An Old Man In The Village" in this story have kinds of deixis like temporal deixis, person deixis, spatial deixis, social deixis and discourse when students' writing there are error analysis like ommission, addition, misinformation and misordering.

For the third, the student tells about "Cinderella" the story have kinds of deixis like temporal deixis, person deixis, spatial deixis, social deixis and discourse when students' writing there are error analysis like ommission, addition, misinformation and misordering. Fourth, student tells story about "Memorable Vocation In Surabaya" that the story have kinds of deixis like temporal deixis, person deixis, spatial deixis, social deixis and discourse when students' writing there are error analysis like ommission, addition, misinformation and misordering.

The fifth, student writes story about "Hunters and Longer Aesop" this story have kinds of deixis like temporal deixis, person deixis, spatial deixis, social deixis and discourse when students' writing there are error analysis like ommission, addition, misinformation and misordering. The sixth student writes about "The Ugly Duckling" the story has kinds of deixis like temporal deixis, person deixis, spatial deixis, social deixis and discourse when students' writing there are error analysis like ommission, addition, misinformation and misordering.

The other student in number 7 writes about "The True Love of Mother" this story has kinds of deixis like temporal deixis, person deixis, spatial deixis, social deixis and discourse when students' writing there are error analysis like ommission, addition, misinformation and misordering. Finally, the student's number 8 is same with student number 3 that written about "Cinderalla" There are some of differences in the error analysis.

\section{Conclusion}

Derived from the result of analysis above, that deixis used on students' writing narrative text. The researchers concluded that there are 5 dexis found in the narrative text like temporal deixis, because showed about time. Second is Person Deixis because there is 
name of the person. Third is spatial deixis because there is a place. Fourth is social. Fifth is discourse.

The researcher also analyzed about students' writing and there is the are error analysis like ommission is the negative false, addition is the adding words or form in the sentences, misinformation is the characterized by use the wrong form and finally is misordering the meaning like the error of putting words in the utterance in the wrong order. From the analysis the researcher found that in the students' narrative texts there are kinds of deixis and error analysis or students' writing.

\section{References}

Avagyan, L. (2019). Types of Writing. Writing Consultant Journal, 1-2.

Defazio, J., Jones, J., Tennant, F., \& Hook, S. A. (2010, June). Academic Literacy: The importance and Impact of Writing Across the Curriculum-A Case Study. Journal of the Scholarship of Teaching and Learning, 10(2), 34-47.

Dulay, H., Burt, M., \& Krashen, S. (1982). Language Two. Oxford: Oxford University Press.

Gafiyatova, W. V., Korovina, I. V., Solnyshkina, M. I., \& Yarmakeev, I. E. (2017). Deixis elements as Means of Text Cohesion and Coherence in Academic Discourse. Journal of Social Studies Education Research, 8(3), 190-200.

Hasanah, U. (2016). A Pragmatic Study on Deixis in the Song Lyrics of Harris J'S "SALAM" Album. Islamic University Maulana Malik Ibrahim, 1-10.

Hutauruk, B. S. (2018). Stylistic Analysis of Deictic Expressions Used on EFL Written Essay Grade III at English Departement at FKIP UHN PERMATANGSIANTAR. Journal of English Language and Culture, 8(2), 98-110.

Kapur, R. (2018). Significance of Research in Education. University of Delhi Journal, 110.

Karolina, I. (2006). Teaching Narrative Text in Improving Writing to the Tenth Grade Students of SMA Negeri 1 Petarukan, Pemalang. Semarang: Universitas Negeri Semarang.

Kreidler, C. W. (1997). Introducing English Semantics. London and New York: ROUTLEDGE.

Kusumaningrum, W. R. (2016, September). Deixis Analysis on Indonesian Shakespeare's Comics Strip of Julius Caesar. Transformatika, 12(2), 73-82.

Kusumaningrum, W. R. (2016). Deixis Analysis on Indonesian Shakespeare's Comics Strip of Julius Caesar. Transformatika, 12(2), 73-82.

Levinson, S. C. (1983). Deixis and Pragmatics. Netherland: MIT Press.

Maulana, H. (2016). Narrative Text. kamikaki.com, 1-10.

Ngadiman, A. (2015). Metode Penelitian Pengajaran Bahasa. Sidoarjo: Laros.

Novianty, F., Saleh, N. J., \& Sukmawaty. (2018). A Comparative Study on Personal Deixis of Engllish and Tukang Besi Language. ELS Journal on Intersisciplinary Studies on Humanities, 1(2), 226-231.

Nurhikmah. (2017). the Function of Deixis Used By EFL Teacher in Classroom Interaction. UMN journal, 1-12.

Patmo, Y. (2017). An Analysis of Deixis and Speech Act Used In English Teaching and Learning Process. Linguistic English Education and Art Journal, 1(1), 82-90.

Purba, N. et al. (2020). Language Acquisition of Children Age 4-5 Years Old in TK Dhinukum Zholtan Deli Serdang. P.19-24

Purba, R. (2018, January). Improving the Achievement on Writing Narrative Text through 
Discussion Starter Story Technique. Advances in Language and Literary Studies, 9(1), 27.

Sari, R. (2015, Septemver). Deixis Analysis through the Interaction among the Students with Different Culture. Transformatika, 11(2), 41-48.

Setiosari, G. S. (2016). The Study of Deixis Used in Shierley Jackson's Short Story the Lottery. Arts and Humanities state Islamic University of Sunan Ampel, 1-10.

Slamet, J. (2020). A Sociolinguistics of Code Mixing and Code Switching Between English and Indonesian Language at STKIP PGRI Sidoarjo. JournEEL (Journal of English Education and Literature), 2(1), 65-77.

Slamet, J., \& Sulistyaningsih, S. (2019). A Syntactic Analysis of Simple Sentence on the Joko Widodo's Speech by Using Theory of Tree Diagram. Journal of English Education (JournE), 1(1), 1-15.

Slamet, J., \& Witjaksono, H. (2019). Types of Deictic Expressions Used in Selected Articles of" The Jakarta Post". Journal of English Education (JournE), 1(2), 11-21.

Silalahi, P. V. (2016). A Highlight on Pragmatics. Parafrase, 16(1), 83-92.

Sulistyaningsih, S., \& Slamet, J. (2018). An Analysis of Conjunctions Found in Barack Obama's Farewell Speech Text. OKARA: Jurnal Bahasa dan Sastra, 12(2), 201-212.

Wibowo, A. B. (2013). Improving Writing Skill by Using Process Writing Approach for Grade X Students of SMA N 1 Kasihan Bantul Yogyakarta In The Academic Year of 2012/2013. English Education Departement Faculty of Languages and Arts Yogyakarta University, 1-10. 